\title{
Hormonal contraception and HPV: a tale of differing and overlapping mechanisms
}

This article was published in the following Dove Press journal:

Open Access Journal of Contraception

2I November 20I I

Number of times this article has been viewed

Morgan A Marks'

Sabra L Klein ${ }^{2,3}$

Patti E Gravitt ${ }^{1,2}$

'Department of Epidemiology, ${ }^{2} \mathrm{~W}$ Harry Feinstone Department of Molecular Microbiology and Immunology, ${ }^{3}$ Department of

Biochemistry and Molecular Biology,

The Johns Hopkins Bloomberg School of Public Health, Baltimore, MD, USA

Correspondence: Morgan Marks

Division of Cancer Epidemiology and

Genetics, National Cancer Institute, 6|20

Executive Blvd, Rockville, MD, USA

Tel + I 3015947097

Email morgan.marks@nih.gov
Abstract: Hormonal contraceptive use is an identified co-factor that modifies cervical cancer risk. The mechanisms by which sex steroid hormones affect the multi-stage natural history of human papillomavirus (HPV) infection and cervical carcinogenesis are still unclear, with no consistent evidence in support of a single biological hypothesis. Understanding the means by which hormonal contraception affects HPV infection and cervical cancer risk may provide critical information to guide future secondary interventions for cancer prevention.

Keywords: hormones, human papillomavirus, cervical cancer

\section{Introduction}

Cervical cancer is the second most common cancer among women worldwide, with an estimated 490,000 cases and 250,000 deaths each year. ${ }^{1}$ High-risk types of anogenital human papillomavirus (HPV), particularly HPV 16 and 18, have been identified as the cause of cervical carcinogenesis and are associated with other anogenital (eg, penile, vaginal, and anal) and non-anogenital (eg, oropharyngeal and tonsillar) cancers., ${ }^{2,3}$ Since their introduction in the late 1960s, the use of hormonal contraceptives that contain either combined estrogen and progesterone (ie, combined oral contraception, COC) or progesterone-only formulations, such as depotmedroxyprogesterone acetate (Depo-Provera; DMPA), has been linked to an increased risk of cervical cancer and is currently considered a co-factor in cervical carcinogenesis. ${ }^{4}$

Long-term use of hormonal contraception is associated with cervical cancer diagnosis in a number of case-control studies which have been analyzed in a series of pooled analyses (Table 1). Large multicenter studies conducted by the International Agency of Research on Cancer (IARC), comprising over 1500 cervical cancer cases and 200 controls, all of whom were HPV positive, identified a nearly 3 -fold increase in the risk of cancer diagnosis among women reporting $>5$ years of COC use. ${ }^{5}$ This increased risk was observed for a period of up to 5 years after cessation of use, with a decreasing risk observed with increasing time since cessation of use (ie, a recency effect). This association was replicated in a pooled analysis of additional case-control and cross-sectional studies. ${ }^{6-8} \mathrm{~A}$ similar increased disease risk has also been observed among women reporting long-term use of progesterone-only contraceptives, eg, depotmedroxyprogesterone acetate (DMPA). ${ }^{67}$ The strength of the association of DMPA use with disease, however, was smaller than the association with COC, suggesting an important role for estrogens in disease risk. 
Table I Summary of studies examining the relationship between hormonal contraceptive use and cervical cancer risk

\begin{tabular}{|c|c|c|c|c|c|c|c|}
\hline Author & $\begin{array}{l}\text { Age of study } \\
\text { population }\end{array}$ & $\begin{array}{l}\text { Study } \\
\text { design }\end{array}$ & $\begin{array}{l}\text { Number of } \\
\text { subjects } \\
\left(\text { studies }^{\mathrm{a}}\right)\end{array}$ & $\begin{array}{l}\text { Number of } \\
\text { disease } \\
\text { outcomes }\end{array}$ & $\begin{array}{l}\text { Hormonal } \\
\text { contraceptive } \\
\text { measured }\end{array}$ & $\begin{array}{l}\text { Contraceptive } \\
\text { metric }\end{array}$ & Result \\
\hline Moreno $^{5}$ & $>35$ & $\mathrm{CC}$ & 1931 & $\begin{array}{l}1465 \text { (ICC) } \\
211 \text { (ISC) }\end{array}$ & $\mathrm{COC}$ & $\begin{array}{l}\text { Ever/never; } \\
\text { duration of use; } \\
\text { recency }\end{array}$ & $\begin{array}{l}\text { Positive association of } \\
\text { long-term COC use with } \\
\text { CxCa diagnosis } \\
\text { Decreasing risk with increasing } \\
\text { time since last use }\end{array}$ \\
\hline Appleby ${ }^{6}$ & NR & pool & $\begin{array}{l}52,082 \\
\text { (24 studies) }\end{array}$ & I6,573 (ICC) & $\mathrm{COC}$ & $\begin{array}{l}\text { Ever/never; } \\
\text { duration of use; } \\
\text { recency }\end{array}$ & $\begin{array}{l}\text { Positive association of long-term } \\
\text { COC use with CxCa diagnosis } \\
\text { among } 24 \text { studies } \\
\text { Decreasing risk with increasing } \\
\text { time since last use }\end{array}$ \\
\hline Smith $^{7}$ & NR & pool & 25 studies & $|2,53|$ & $\mathrm{COC}$ & $\begin{array}{l}\text { Ever/never; } \\
\text { duration of use; } \\
\text { recency }\end{array}$ & $\begin{array}{l}\text { Long-term use of combined } \\
\text { oral contraception associated } \\
\text { with } \mathrm{CxCa} \text { diagnosis } \\
\text { Decreasing risk with increasing } \\
\text { time since last use }\end{array}$ \\
\hline $\mathrm{ICoESoC}^{8}$ & NR & pool & $\begin{array}{l}35,916 \\
\text { (12 studies) }\end{array}$ & $\begin{array}{l}8097 \text { (SCC) } \\
1374 \text { (ADC) }\end{array}$ & $\mathrm{COC}$ & $\begin{array}{l}\text { Ever/never; } \\
\text { duration of use; } \\
\text { recency }\end{array}$ & $\begin{array}{l}\text { Per year increase in } C O C \text { use } \\
\text { associated with an increased risk } \\
\text { of SCC and ADC } \\
\text { Decreasing risk with increasing } \\
\text { time since last use }\end{array}$ \\
\hline Appleby ${ }^{6}$ & NR & pool & 3 studies & I6,573 (ICC) & DMPA & $\begin{array}{l}\text { Ever/never; } \\
\text { duration of use; } \\
\text { recency }\end{array}$ & $\begin{array}{l}\text { Long-term use of DMPA associated } \\
\text { with an increase risk of } \mathrm{CxCa} \\
\text { Decreasing risk with increasing } \\
\text { time since last use }\end{array}$ \\
\hline Smith ${ }^{7}$ & NR & pool & 3 studies & $|2,53|$ & DMPA & $\begin{array}{l}\text { Ever/never; } \\
\text { duration of use; } \\
\text { recency }\end{array}$ & $\begin{array}{l}\text { Long-term use of DMPA } \\
\text { marginally associated with } \\
\text { an increase risk of } \mathrm{CxCa} \\
\text { Decreasing risk with increasing } \\
\text { time since last use }\end{array}$ \\
\hline
\end{tabular}

Note: ${ }^{\text {F}}$ or meta-analyses or studies involving pooled data.

Abbreviations: CxCa, cervical cancer; ICC, invasive cervical cancer; ISC, in situ carcinoma; SCC, squamous cell carcinoma; ADC, adenocarcinoma; COC, combined oral contraceptive; DMPA, depotmedroxyprogesterone acetate; NR, not reported; pool, pooled studies.

These case-control studies are limited by their inability to distinguish how and when hormonal contraceptives increase cervical cancer risk. Hormonal contraceptives may affect risk at any point in the 10- to 20-year natural history of cervical cancer, yet case-control designs cannot allow investigation of the temporal effects of exposure on upstream transitions. Prospective and case-control observational studies that test associations at multiple early transitions in the course of cervical cancer development may provide corollary evidence addressing alternative mechanisms by which hormonal contraceptives facilitate carcinogenesis.

Several hypotheses have been proposed to explain the observed relationship between hormonal contraceptive use, HPV, and cervical cancer risk. These hypotheses include: (1) sex steroid hormones mediate cervical ectopy leading to enhanced acquisition of HPV, (2) sex steroid hormones modulate the host immune response to HPV, facilitating viral persistence and development of pre-cancerous lesions, and (3) sex steroid hormones increase risk of development of pre-cancerous lesions and progression to invasive cancer. We review the observational and experimental data addressing these alternative hypotheses to provide a framework by which to evaluate the collective evidence for the role of hormonal contraceptives on HPV and cervical cancer.

\section{Hypothesis I: sex steroid hormones contribute to cervical ectopy and increase acquisition of HPV}

In many populations, women using oral contraceptives may be more sexually active and have more risky sexual behavior (eg, do not use condoms) than women not using hormonal contraception..$^{9,10}$ Because of increased sexual risk, it is reasonable to consider that hormonal contraceptive users are more likely to acquire HPV infection and, thus, have an 
increased risk of cervical cancer - such that the associations observed between hormonal contraceptive use and cervical cancer are explained by residual confounding variables. However, analyses that were restricted to HPV positive cases and controls only, report a similarly elevated risk of cervical cancer among long duration oral contraceptive users. Thus, residual confounding is unlikely to explain the majority of the increased risk.

Because hormonal contraception has been shown to maintain the presence of columnar epithelial cells in the ectocervical region as well as in the transformation zone in a condition known as cervical ectopy, ${ }^{11-14}$ others have hypothesized that hormone contraceptive users are more biologically susceptible to HPV infection given exposure. ${ }^{4}$ As reviewed below, while animal models show some support for an increased susceptibility to infection in the ectopic cervix, the observational associations between hormonal contraceptive use, ectopy, and HPV persistence/incidence are less clear.

\section{Murine models of HPV pseudovirus infection: role of progesterone}

Mouse models of HPV infection have been developed to identify putative receptors and mechanisms responsible for HPV viral particle entry. In these models, HPV pseudoviral particles are used for experimental infection, and represent fully assembled capsid protein, comprising the two viral structural proteins, L1 and L2, coupled to a fluorescent reporter dye, allowing in vivo tracking of the location of the pseudovirus through infection in the basal epithelium. ${ }^{15}$ In these models, experimental animals are treated with DMPA for at least 4 days to thin the squamous epithelium and reduce variability of the epithelium across the menstrual cycle to allow for increased uptake of pseudovirus particles, supporting a hormonedependent increase in infection susceptibility. ${ }^{16}$ Because no change in the maturity state of the cervix or position of the transformation zone has been observed among women using progesterone-only contraceptives, whether the effects of progesterone on virus entry occur in humans remains to be demonstrated. ${ }^{17,18}$

\section{Association of COC use or ectopy and HPV prevalence}

Current and long-term use of COCs ( $>6$ years) has been associated with prevalent HPV infection in cross-sectional studies $^{19}$ (Table 2). This association was more likely to be observed among women $<35$ years of age ${ }^{20-26}$ than among older women. ${ }^{5,27,28}$ Current and previous use of DMPA for at least 1 year was observed in two studies to be associated with a higher prevalence of HPV among women at or around the age of 30 years. ${ }^{29,30}$ Because contraceptive users may engage in riskier sexual behaviors more frequently than non-users, these studies carefully controlled for these behavioral differences, as well as for vaginal cytological abnormalities. Of the three cross-sectional studies that directly assessed ectopy and prevalence of HPV infection, only one showed a significant positive association. ${ }^{31}$ Interestingly, hormonal contraceptive use in this study was not associated with increased HPV prevalence, although the authors failed to make a distinction by type of contraceptive method utilized. The remaining two studies either failed to see a significant association $^{32}$ or observed an inverse association of ectopy and HPV prevalence. ${ }^{33}$

\section{Association of COC use with new detection of HPV}

Combined oral contraception has been the primary contraceptive method explored in relation to new detection of HPV (Table 3). Among college-aged women with 4 years of follow-up, as well as among women 20-29 years of age enrolled in a population-based study with 2 years of follow-up, current and long-term use of COC was positively associated with new detection of HPV, which was significantly attenuated after adjustment for sexual behavior. ${ }^{34,35}$ Conversely, among adolescent women recruited from STD clinics with 2 years of follow-up, women who used COCs were at a reduced risk of developing new HPV infections. ${ }^{36}$ Another study of women 30-33 years of age reported no significant association of hormonal contraceptive use and HPV infection after adjustment for sexual behavior. ${ }^{37}$ Recently, we explored the association between new HPV detection and hormonal contraceptive use in a large prospective study conducted in Zimbabwe, Uganda, and Thailand that was designed to evaluate the association between hormonal contraceptive use and HIV acquisition. ${ }^{38}$ We restricted the HPV substudy to the 1135 women enrolled in Thailand which had negligible HIV seroconversion during follow-up, to enhance the generalizability of our results. In this study which purposefully sampled an equal number of non-hormonal contraceptive users, long-term COC users, and long-term DMPA users, the increased risk of new HPV detection among COC users observed in univariate analysis was significantly attenuated after adjustment for sexual risk behavior. ${ }^{39}$ In addition, we found no association between cervical ectopy and new detection of HPV in this study.

The relatively large effect of sexual risk on attenuating the strength and significance of the association of COC use with new detection of HPV suggests that differences in the 
Table 2 Summary of studies examining the association between hormonal contraceptives and HPV prevalence

\begin{tabular}{|c|c|c|c|c|c|c|}
\hline Author & $\begin{array}{l}\text { Mean age of } \\
\text { study population } \\
\text { (range) }\end{array}$ & $\begin{array}{l}\text { Study } \\
\text { design }\end{array}$ & $\begin{array}{l}\text { Number of } \\
\text { subjects }\end{array}$ & $\begin{array}{l}\text { Hormonal } \\
\text { contraceptive } \\
\text { assessed }\end{array}$ & $\begin{array}{l}\text { Contraceptive } \\
\text { metric }\end{array}$ & Result \\
\hline Burk 20 & 20.4 & $x$ & 604 & $\mathrm{COC}$ & Current use & $\begin{array}{l}\text { Current COC users had an } \\
\text { increased risk of HPV infection }\end{array}$ \\
\hline Kjaer $^{21}$ & $20-29$ & $x$ & 1000 & $\mathrm{COC}$ & Duration & $\begin{array}{l}\text { Users for }>5 \text { years increased } \\
\text { risk of HPV infection }\end{array}$ \\
\hline Ley $^{22}$ & 22.9 & $x$ & 467 & $\mathrm{COC}$ & $\begin{array}{l}\text { Ever use; } \\
\text { duration }\end{array}$ & $\begin{array}{l}\text { Current, past, short ( } 1 \text { year) } \\
\text { and long term use ( }>6 \text { years) } \\
\text { associated with HPV infection }\end{array}$ \\
\hline Pham 25 & $15-65$ & $x$ & 922 & $\mathrm{COC}$ & $\begin{array}{l}\text { Current; } \\
\text { past use }\end{array}$ & $\begin{array}{l}\text { Current use associated with } \\
\text { HPV infection }\end{array}$ \\
\hline Rousseau ${ }^{26}$ & 33.3 & $\mathrm{CC}$ & 729 & $\mathrm{COC}$ & Duration & $\begin{array}{l}\text { Short }(<6) \text { and long term } \\
(>6) \text { duration associated with } \\
\text { HR-HPV and HPV } 16 \text { infection }\end{array}$ \\
\hline Kotloff ${ }^{24}$ & 22.5 & $x$ & 414 & $\mathrm{COC}$ & Current use & $\begin{array}{l}\text { Current use marginally } \\
\text { associated with HPV }\end{array}$ \\
\hline Marks ${ }^{23}$ & 29.6 & $x$ & 1070 & $\mathrm{COC}$ & $\begin{array}{l}\text { Current use; } \\
\text { duration; ever use }\end{array}$ & $\begin{array}{l}\text { Use for }>6 \text { years associated } \\
\text { with an increased risk of HPV }\end{array}$ \\
\hline Molano ${ }^{28}$ & $>35$ & $x$ & 1859 & $\mathrm{COC}$ & $\begin{array}{l}\text { Ever use; } \\
\text { current use }\end{array}$ & $\begin{array}{l}\text { Positive association among } \\
\text { current users (LR HPV types only) }\end{array}$ \\
\hline Vaccarella $^{27}$ & $>35$ & $x$ & 15,145 & $\mathrm{COC}$ & $\begin{array}{l}\text { Current use; } \\
\text { duration }\end{array}$ & No association \\
\hline Moreno ${ }^{5}$ & $>35$ & CC (controls) & 1916 & $\mathrm{COC}$ & Ever use; duration & No association \\
\hline Harris $^{29}$ & $18-50$ & $\mathrm{CC}$ & 724 & DMPA & $\begin{array}{l}\text { Recent use; } \\
\text { duration of use }\end{array}$ & $\begin{array}{l}>I \text { year of DMPA use associated } \\
\text { with an increased risk of } \\
\text { HR-HPV infection }\end{array}$ \\
\hline Giuliano $^{30}$ & 33.1 & $x$ & 2319 & DMPA & $\begin{array}{l}\text { Current vs } \\
\text { former use }\end{array}$ & $\begin{array}{l}\text { Current use associated with } \\
\text { an increased risk of } \\
\text { HR-HPV infection }\end{array}$ \\
\hline Marks ${ }^{23}$ & 29.6 & $x$ & 1070 & DMPA & $\begin{array}{l}\text { Current use; } \\
\text { duration; ever use }\end{array}$ & $\begin{array}{l}\text { No association with current } \\
\text { or prior use }\end{array}$ \\
\hline
\end{tabular}

Notes: Light gray = null association, white = positive association.

Abbreviations: COC, combined oral contraception; DMPA, depomedroxyprogesterone acetate; HR-HPV, high-risk human papillomavirus; HPV, human papillomavirus; $\mathrm{X}$, cross-sectional; CC, case-control.

sexual practices of hormonal contraceptive users may be driving the univariate associations. Furthermore, the residual positive association observed after adjustment, albeit small, may be a result of unmeasured sexual behaviors and not a result of the biological influence of COC use on facilitating new detection of HPV.

\section{Hypothesis 2: sex steroid hormones modulate the host immune response to HPV, facilitating viral persistence and development of pre-cancerous lesions}

If the higher prevalence of HPV among current and long-term hormonal contraceptive users does not appear to be explained by an increased risk of HPV acquisition, it is possible that hormonal contraceptive use leads to an increased risk of persistent infection. Viral persistence is a key risk factor for high grade HPV disease and cervical cancer and appears to be associated with deficiencies in the CD4+ and CD8+ cytotoxic T lymphocyte (CTL) response. ${ }^{40-42}$ Women with persistent HPV infection and cervical lesions have reduced in vitro lymphoproliferation responses to immunological stimulants (eg, phytohemagglutinin mitogen or HPV-specific antigens), lower circulating IFN- $\gamma$, higher IL-10, and enhanced regulatory T-cell function, as represented by detection of Foxp3 mRNA transcripts. ${ }^{43,44}$ Sex steroid hormones can directly alter immune cell function by binding to intracellular receptors and altering transcription of immune-mediated genes, ${ }^{45,46}$ resulting 
Table 3 Summary of studies evaluating the association between hormonal contraceptive use and new detection of HPV

\begin{tabular}{|c|c|c|c|c|c|c|}
\hline Author & $\begin{array}{l}\text { Mean age of } \\
\text { study population } \\
\text { (range) }\end{array}$ & $\begin{array}{l}\text { Number } \\
\text { of subjects }\end{array}$ & $\begin{array}{l}\text { Mean length of } \\
\text { follow-up (sampling } \\
\text { frequency) }\end{array}$ & $\begin{array}{l}\text { Hormonal } \\
\text { contraceptive } \\
\text { assessed }\end{array}$ & $\begin{array}{l}\text { Contraceptive } \\
\text { metric }\end{array}$ & Result \\
\hline Moscicki $^{36}$ & 20 & 105 & $\begin{array}{l}2 \text { years } \\
\text { (6 months) }\end{array}$ & $\mathrm{COC}$ & $\begin{array}{l}\text { Current use } \\
\text { at FU }\end{array}$ & $\begin{array}{l}\text { COC users less likely } \\
\text { to have an incident HPV } \\
\text { infection after adjustment } \\
\text { for sexual behavior }\end{array}$ \\
\hline Nielsen ${ }^{34}$ & $20-29$ & 5448 & $\begin{array}{l}2 \text { years } \\
(2 \text { years })\end{array}$ & $\mathrm{COC}$ & $\begin{array}{l}\text { Current use } \\
\text { at FU; duration }\end{array}$ & $\begin{array}{l}\text { Positive, marginal increase } \\
\text { among current user } \\
\text { and user for }>6 \text { years } \\
\text { associated after adjustment } \\
\text { for sexual behavior }\end{array}$ \\
\hline Sellors ${ }^{37}$ & 33 & 307 & $\begin{array}{l}\text { I year } \\
\text { (12 months) }\end{array}$ & $\mathrm{COC}$ & $\begin{array}{l}\text { Current use } \\
\text { at FU }\end{array}$ & No association \\
\hline Winer ${ }^{35}$ & 19 & 444 & $\begin{array}{l}4 \text { years } \\
(4 \text { months })\end{array}$ & $\mathrm{COC}$ & $\begin{array}{l}\text { Current use } \\
\text { at FU }\end{array}$ & $\begin{array}{l}\text { Positive, marginal } \\
\text { association after adjustment } \\
\text { for sexual behavior }\end{array}$ \\
\hline Marks ${ }^{39}$ & 29.6 & 1135 & $\begin{array}{l}18 \text { months } \\
\text { (6 months) }\end{array}$ & COC/DMPA & $\begin{array}{l}\text { Current use } \\
\text { at FU }\end{array}$ & $\begin{array}{l}\text { Positive, non-significant } \\
\text { association after adjustment } \\
\text { for sexual behavior }\end{array}$ \\
\hline
\end{tabular}

Notes: Light gray = null association, white = positive association, black = negative association.

Abbreviations: COC, combined oral contraceptive; DMPA, depotmedroxyprogesterone acetate; FU, follow-up.

in pronounced effects on the course of infectious diseases. ${ }^{47-50}$ Therefore, use of hormonal contraceptives may compromise protective immunity against HPV, leading to a reduced rate of HPV clearance and increased rate persistence.

\section{Sex steroid hormones and host immunity}

The effects of sex steroid hormones such as estradiol and progesterone on host immunity have been evaluated using both in vitro model systems and direct measures in women using exogenous hormones. Higher estradiol and progesterone serum concentrations in pregnant women correlate with higher concentrations of IgG, IgA, and IL-1 $\beta$ in the cervical mucus collected during each trimester, suggesting that changes in sex steroid hormones can alter the cervical immunological microenvironment. ${ }^{51}$ Functional differences in T-cell response have been reported in pregnant versus non-pregnant women, and in exogenous hormone users relative to non-users. Peripheral T-cells isolated from pregnant women produce more anti-inflammatory cytokines, including IL-4 and IL-10, than do cells from nonpregnant women. ${ }^{52}$ Women taking hormone replacement therapy (estradiol alone or combined with progesterone) had lower concentrations of IL- $1 \beta,{ }^{53} \mathrm{TNF}-\alpha,{ }^{53,54} \mathrm{IFN}-\gamma,{ }^{55,56} \mathrm{IL}-6,{ }^{54,57}$ and IL- $2^{55}$ reduced natural killer cell activity, ${ }^{58,59}$ and higher concentrations of IL-1 $\mathrm{ra}^{60}$ and total immunoglobulin ${ }^{61}$ in cultured peripheral blood mononuclear cells. The differences in the concentrations of circulating sex steroid hormones in pregnancy and among exogenous hormone users limit the ability to draw any conclusions about the mechanistic influence of estradiol and progesterone on the immune system. In fact, estradiol has been reported to have qualitatively different effects on peripheral blood mononuclear cells (PBMCs) according to concentration used. At concentrations simulating pregnancy levels $\left(10^{-7} \mathrm{M}\right)$, estradiol reduces TNF- $\alpha^{53,54,62-64}$ and IL- $1 \beta,,^{53,65-67}$ induces the production of polyclonal antibodies, ${ }^{68,69}$ and upregulates somatic hypermutation and class-switch recombination in B-cells. ${ }^{70}$ Estradiol at pregnancy-level concentrations also induces IL-10 production ${ }^{64,68,69,71}$ and increases in CD4+CD25+ regulatory $\mathrm{T}$ cell function. ${ }^{72,73}$ At lower concentrations relevant to the menstrual cycle among non-pregnant women $\left(10^{-8}\right.$ $M-10^{-10} \mathrm{M}$ ), estradiol increases production of IL- $1 \beta$, TNF- $\alpha$, IFN- $\gamma$, and IL-12. ${ }^{62,66,67,71,74}$ Lastly, we found that estradiol and progesterone alone, in combination at concentrations relevant to COC use (E2: $10^{-8} \mathrm{M}$; P4: $10^{-6} \mathrm{M}$, or $10^{-10} \mathrm{M}$ ), increased the concentration of IL-10, TGF- $\beta$, and FoxP3 and decreased the concentration of IFN- $\gamma$, TNF- $\alpha$, and IL-12p70 in PBMCs isolated from healthy donor women stimulated with HPV 16 VLP in vitro. ${ }^{75}$

Although experimental data on the effects of progesterone are scarce, it is regarded primarily as immunosuppressive. Progesterone at pregnancy concentrations suppresses regulatory $\mathrm{T}$ cell function and increases production of IL-4 and IL-5 in vitro. ${ }^{76,77}$ Lastly, in mouse models of herpes simplex type-2 
(HSV-2) infection, progesterone has been shown to alter mucosal immune responses including suppression of local immunoglobulin production in response to vaginal HSV-2 challenge, leading to enhanced susceptibility of infection as well as enhanced inflammation and pathology and mortality. ${ }^{78}$

\section{Sex steroid hormones and HPV persistence}

Persistence of HPV is a pivotal step in the natural history of cervical cancer (Table 4). ${ }^{79}$ The association between current use of COCs or DMPA and HPV persistence is highly variable across study populations. Three studies, two conducted among college age women with $2^{80}$ and 10 years ${ }^{81}$ of follow-up and another among early adolescent females ${ }^{82}$ attending inner-city family planning clinics with 2 years of follow-up showed no association between current COC use and HPV persistence. A population-based study conducted among 20- to 29-year-old women in Denmark with up to
2 years of follow-up observed an association of current COC use with an increased risk of HPV persistence. ${ }^{83} \mathrm{We}$ observed similar associations in our prospective study of women aged 20-30 years recruited from family-planning clinics in Thailand who reported longer term use of hormonal contraception. ${ }^{39}$ Among women $>30$ years of age, a large prospective study of 1700 individuals from Colombia with more than 6 years of follow-up reported no association of COC use with HPV persistence. ${ }^{84,85}$ Conversely, DMPA use was associated with an increased risk of HPV clearance in a single study conducted in a triage population of young women with mild cervical abnormalities. ${ }^{86}$

The elevated risk of HPV persistence among COC users in population-based studies of women 20-30 years of age or women accessing family planning services suggests that, similar to measurement of the effects of hormonal contraception on invasive cancer risk, duration of exposure to exogenous

Table 4 Summary of studies examining the relationship between hormonal contraceptives and HPV persistence

\begin{tabular}{|c|c|c|c|c|c|c|c|}
\hline Author & $\begin{array}{l}\text { Age of study } \\
\text { population } \\
\text { (range) }\end{array}$ & $\begin{array}{l}\text { Number } \\
\text { of subjects }\end{array}$ & $\begin{array}{l}\text { Infection } \\
\text { types } \\
\text { included }\end{array}$ & $\begin{array}{l}\text { Mean length } \\
\text { of FU (sampling } \\
\text { frequency) }\end{array}$ & $\begin{array}{l}\text { Hormonal } \\
\text { contraceptive } \\
\text { assessed }\end{array}$ & $\begin{array}{l}\text { Contraceptive } \\
\text { metric }\end{array}$ & Result \\
\hline Maucort-Boulch ${ }^{86}$ & 25 & 2408 & Both & $\begin{array}{l}2 \text { years } \\
\text { (6 months) }\end{array}$ & $\mathrm{COC}$ & $\begin{array}{l}\text { Current use } \\
\text { at enrollment }\end{array}$ & $\begin{array}{l}\text { No association } \\
\text { with } \mathrm{COC} \text { use }\end{array}$ \\
\hline Molano ${ }^{85}$ & 29 & 227 & Prevalent & $\begin{array}{l}6 \text { years } \\
\text { (6 months) }\end{array}$ & $\mathrm{COC}$ & Ever/never & $\begin{array}{l}\text { Ever use was } \\
\text { positively, marginally } \\
\text { associated with HPV } \\
\text { viral clearance }\end{array}$ \\
\hline Munoz $^{84}$ & $>35$ & 2139 & Both & $\begin{array}{l}9 \text { years } \\
\text { (6 months) }\end{array}$ & $\mathrm{COC}$ & Ever/never & No association \\
\hline Nielsen ${ }^{83}$ & $20-29$ & 1166 & Prevalent & $\begin{array}{l}2 \text { years } \\
(2 \text { years })\end{array}$ & $\mathrm{COC}$ & Current/former & $\begin{array}{l}\text { Current use of } \\
\text { COCs associated } \\
\text { with HPV } \\
\text { persistence }\end{array}$ \\
\hline
\end{tabular}

\begin{tabular}{|c|c|c|c|c|c|c|c|}
\hline Richardson ${ }^{80}$ & $17-27$ & 327 & Both & $\begin{array}{l}2 \text { years } \\
\text { (6 months) }\end{array}$ & $\mathrm{COC}$ & $\begin{array}{l}\text { Current use; } \\
\text { duration of use }\end{array}$ & No association \\
\hline Shew ${ }^{82}$ & 15 & 49 & Both & $\begin{array}{l}2 \text { years } \\
\text { (3 months) }\end{array}$ & $\mathrm{COC}$ & Current use & No association \\
\hline Sycuro ${ }^{81}$ & 19 & 147 & Incident & $\begin{array}{l}10 \text { years } \\
\left(10 \text { years }^{\mathrm{a}}\right)\end{array}$ & $\mathrm{COC}$ & $\begin{array}{l}\text { Current use } \\
\text { at long-term } \\
\text { FU visit }\end{array}$ & No association \\
\hline Marks ${ }^{39}$ & 29.6 & 1135 & Both & $\begin{array}{l}18 \text { months } \\
\text { (6 months) }\end{array}$ & $\mathrm{COC}$ & $\begin{array}{l}\text { Current use } \\
\text { at FU }\end{array}$ & $\begin{array}{l}\text { Current use of } \\
\text { COCs associated } \\
\text { with HPV } \\
\text { persistence }\end{array}$ \\
\hline Maucort-Boulch ${ }^{86}$ & 25 & 2408 & Both & $\begin{array}{l}2 \text { years } \\
\text { (6 months) }\end{array}$ & DMPA & $\begin{array}{l}\text { Current use } \\
\text { at enrollment }\end{array}$ & $\begin{array}{l}\text { DMPA associated } \\
\text { with HPV clearance }\end{array}$ \\
\hline Marks ${ }^{39}$ & 29.6 & 1135 & Both & $\begin{array}{l}18 \text { months } \\
\text { (6 months) }\end{array}$ & DMPA & $\begin{array}{l}\text { Current use } \\
\text { at FU }\end{array}$ & No association \\
\hline
\end{tabular}

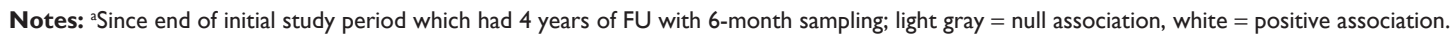
Abbreviations: COC, combined oral contraception; DMPA, depotmedroxyprogesterone acetate (Depo-Provera); FU, follow-up; HPV, human papillomavirus. 
hormones is an important metric. If this is the case, the lack of association between COC use and HPV persistence in studies conducted among adolescent and college-aged women could be explained by a selection bias, where study participants may not have accrued adequate exposure time since sexual debut to observe a longer term effect on persistent infection. The possible impact of duration of hormone use reinforces the need to measure prior and current use of hormonal contraception in order to stratify study subjects by their estimated cumulative exposure.

\section{Hypothesis 3: sex steroid hormones increase risk of development of pre-cancerous lesion and progression to invasive cancer}

In vitro exposure to sex steroids alters E6/E7 HPV gene expression

Interpretation of the observational studies assessing the relationship of sex steroid hormones on HPV-related disease endpoints have been guided primarily by mechanistic hypotheses that sex steroids increase carcinogenic potential through interaction with either the virus or host. Cell culture models utilizing immortalized epithelial-derived cells have been the most efficient system to assess the effects of estradiol and progesterone on viral factors (Table 5). The effect of estradiol and progesterone on HPV transcription has been evaluated in epithelial cell lines immortalized through transfection with whole genomes of HPV 16 or 18, or with high-risk E6/E7 oncogenes alone. Estradiol, at concentrations similar to late-term pregnancy $\left(10^{-6} \mathrm{M}\right.$ or $\left.10^{-7} \mathrm{M}\right)$, increases the expression of HPV 16 E6/E7 transcripts in HPV containing SiHa and CaSki cell lines. ${ }^{87-90}$ Estradiol also increases cellular proliferation and reduces apoptotic potential in both $\mathrm{SiHa}$ and CaSki cell lines. ${ }^{90,91}$ Exposure of SiHa and CaSki cells to progesterone at concentrations consistent with those found during late-term pregnancy $\left(10^{-6} \mathrm{M}\right.$ or $\left.10^{-7} \mathrm{M}\right)$ also increases HPV gene expression and cell proliferation. ${ }^{87,89}$ Treatment of these cell lines with progesterone and estrogen

Table 5 Summary of studies evaluating the effects of sex steroid hormones on HPV in vitro

\begin{tabular}{|c|c|c|c|}
\hline Author & Experimental model & Hormone treatment [C] & Result \\
\hline Mitrani-Rosenbaum ${ }^{88}$ & SiHa cells (HPV I6) & $\begin{array}{l}\text { I7 } \beta \text {-estradiol } \\
{\left[10^{-6} \mathrm{M}\right]}\end{array}$ & $\begin{array}{l}\text { Estrogen stimulates HPV } 16 \\
\text { transcript expression } \\
\text { Estrogen response elements } \\
\text { identified on HPV } 16 \text { genome }\end{array}$ \\
\hline Hwang ${ }^{92}$ & SFR (CaSki derivative) (HPV I6) & $\begin{array}{l}\text { Tamoxifen } \\
{\left[10^{-9} \text { thru } 10^{-11} \mathrm{M}\right]}\end{array}$ & $\begin{array}{l}\text { Tamoxifen induces HPV I } 6 \text { mRNA } \\
\text { expression and E7 expression }\end{array}$ \\
\hline Chen $^{87}$ & $\begin{array}{l}\text { HeLa cells w/plasmids containing } \\
\text { LCR for HPV I6 and I8 (HPV I8) }\end{array}$ & $\begin{array}{l}17 \beta \text {-estradiol }\left[10^{-7} \mathrm{M}\right] \\
\text { progesterone }\left[10^{-7} \mathrm{M}\right]\end{array}$ & $\begin{array}{l}\text { Both sex steroid hormones as well } \\
\text { as derivatives increased HPV } 16 \text { LCR } \\
\text { expression in the CAT reporter } \\
\text { assay system }\end{array}$ \\
\hline $\mathrm{Kim}^{91}$ & $\begin{array}{l}\text { HeLa (HPV I8), CaSki (HPV I6), } \\
\text { C33a (control) }\end{array}$ & $17 \beta$-estradiol $\left[10^{-6} \mathrm{M}\right]$ & $\begin{array}{l}\text { HeLa and CaSki were stimulated } \\
\text { by estradiol at }\left[10-^{6} \mathrm{M}\right] \text { and }\left[10-^{7} \mathrm{M}\right] \\
\text { Estradiol suppressed HeLa proliferation }\end{array}$ \\
\hline Ruutu 90 & CaSki and $\mathrm{SiHa}$ (HPV I6) & $\begin{array}{l}\text { I7 } \beta \text {-estradiol; progesterone; } \\
\text { tamoxifen; RU486 }\end{array}$ & $\begin{array}{l}\text { No effect of hormone treatment } \\
\text { on HPV } 16 \text { E6/E7 expression } \\
\text { Progesterone increased cell proliferation } \\
\text { in both cell lines while } 17 \beta \text {-estradiol in SiHa only } \\
\text { I7 } 3 \text {-estradiol protected CaSki cells } \\
\text { from apoptosis while progesterone enhanced } \\
\text { apoptosis in CaSki cells } \\
\text { RU486 abrogated progesterone effects while } \\
\text { tamoxifen had no effect on estrogen }\end{array}$ \\
\hline Mittal ${ }^{89}$ & SiHa cells (HPV I6) & $\begin{array}{l}\text { Progesterone } \\
{\left[10^{-6} \mathrm{M}\right]}\end{array}$ & $\begin{array}{l}\text { Progesterone increased HPV I6 E6/E7 } \\
\text { mRNA expression }\end{array}$ \\
\hline Marks ${ }^{75}$ & Human PBMCs & $\begin{array}{l}\text { E2 }\left[10^{-8} \mathrm{M}\right] \\
\text { P4 }\left[10^{-6} \mathrm{M} / 10^{-10} \mathrm{M}\right]\end{array}$ & $\begin{array}{l}\text { Upon stimulation with HPV I6 VLP single and } \\
\text { combined treatments of E2 and P4 resulted in: } \\
\text { I) Decrease [c] of IL-12p70, TNF- } \alpha \text {, and IFN- } \gamma \\
\text { 2) Increased [c] of IL-10, IL-6, IL-I ra, TGF- } \beta \text {, } \\
\text { and Foxp3 }\end{array}$ \\
\hline
\end{tabular}

Abbreviation: PBMCs, peripheral blood mononuclear cells. 
antagonists, including RU486 and tamoxifen, respectively, has shown differential effects. Although RU486 was effective at reversing progesterone-induced HPV gene expression and cellular proliferation, tamoxifen was significantly less effective. ${ }^{89,90}$ At low concentrations, tamoxifen stimulated growth of CaSki cells, and induced HPV 16 E7 gene expression. ${ }^{91,92}$ These data illustrate the complexities of the relationship between sex steroid hormone signaling.

Transgenic murine model of cervical carcinogenesis reveals direct effects

of sex steroids on carcinogenesis

Transgenic mouse models that contain HPV 16 E6/E7 genes under the control of a keratin promoter (K14-HPV16E6/E7) have been useful in identifying a potential role of estradiol on host-mediated cervical carcinogenesis (Table 6). The development of cervical tumors in these mice is dependent on treatment with estradiol for at least 6 months and the presence of HPV 16 E6..$^{93-95}$ The dose of estradiol is positively correlated with tumor size and cessation of estradiol treatment after 6 months leads to tumor regression. ${ }^{93}$ Interestingly, estradiol exposure does not appear to be associated with increasing HPV 16 mRNA oncogene expression as measured using in situ hybridization. ${ }^{95}$ Treatment of these mice with ICI 182,780, an estrogen receptor antagonist, or raloxifene, a selective estrogen receptor modulator, is highly effective at clearing tumors and precursor lesions. ${ }^{96}$ However, it is important to consider that these experimental models focus primarily on the impact of estradiol alone (without progesterone) on HPV oncogene-associated carcinogenesis and do not explore the effects of sex steroids on the host immune responses to tumor surveillance and/or infection.

\section{Effect of sex steroid hormones on increased risk of cervical intraepithelial neoplasia grade 2 or 3}

The association of hormonal contraceptive use on the development of cancerous precursor lesions such as high grade squamous intraepithelial lesions or cervical intraepithelial neoplasia grade 2 or 3 (CIN 2/3) among women with preexisting HR-HPV infections has been inconsistent across studies (Table 7). Prospective studies that followed HR-HPV positive women between the ages of 20-30 without evidence of prevalent cervical disease for development of CIN 2/3 have been unable to identify a consistent positive association with COC use, but did observe a positive association with CIN 2/3 among users of DMPA. ${ }^{97,98}$ Among adolescent women diagnosed with CIN 2/3, current use of COC was observed to reduce the likelihood of lesion regression. ${ }^{99} \mathrm{Case}-$ control studies that included HR-HPV positive women with histologically confirmed CIN 2/3 compared with age- and

Table 6 Summary of the effects of estradiol on HPV-mediated cervical carcinogensis in mice

\begin{tabular}{|c|c|c|c|}
\hline Author & Experimental model & Hormone treatment ${ }^{a}$ & Result \\
\hline Shai ${ }^{94}$ & KI4E6/E7 transgenic mice & $\begin{array}{l}\text { I7 } \beta \text {-estradiol for } 9 \text { months } \\
\text { (0.05 mg/60 days) }\end{array}$ & $\begin{array}{l}\text { E6 alone (without E7) cooperates } \\
\text { with I7 } 3 \text {-estradiol to induce } \\
\text { lesions after } 9 \text { months }\end{array}$ \\
\hline Arbeit $^{95}$ & KI4-E6/E7 transgenic mice & $\begin{array}{l}\text { I7 } \beta \text {-estradiol for } 6 \text { months } \\
(0.25-0.72 \mathrm{mg} / 60 \text { days })\end{array}$ & $\begin{array}{l}\text { Estradiol increases development } \\
\text { of dysplasia and hyperplasia only } \\
\text { among mice with HPV I } 6 \text { E6/E7 transgenes } \\
\text { HPV I6 E6/E7 mRNA expression was not } \\
\text { affected by estradiol trt }\end{array}$ \\
\hline Chung $^{96}$ & KI4-E6/E7 transgenic mice & $\begin{array}{l}\text { I7 } \beta \text {-estradiol for } 6 \text { months } \\
(0.05 \mathrm{mg} / 60 \text { days })\end{array}$ & $\begin{array}{l}\text { Treatment of mice with } \mathrm{ICI} \text {, an estrogen } \\
\text { receptor antagonist and raloxifene, } \\
\text { a selective ER modulator, cleared cancer } \\
\text { and precursors of the cervix and vagina } \\
\mathrm{ICI} \text { was capable of preventing } \\
\text { progression of lesions }\end{array}$ \\
\hline Brake $^{93}$ & KI4E6/E7 transgenic mice & $\begin{array}{l}\text { I7 } \beta \text {-estradiol for } 6 \text { months } \\
(0.05 \mathrm{mg} / 60 \text { days })\end{array}$ & $\begin{array}{l}\text { Estrogen treatment induced tumor } \\
\text { formation in transgenic mice } \\
\text { Tumor number and size was positively } \\
\text { correlated with the amount } \\
\text { of exposure to estrogen } \\
\text { Removal of estrogen exposure after } \\
6 \text { months led to tumor regression }\end{array}$ \\
\hline
\end{tabular}

Note: ${ }^{a} 17 \beta$-estradiol administered subcutaneously as a pellet every 60 days.

Abbreviations: $\mathrm{ICI}$, ICI I82,780; ER, estrogen receptor; HPV, human papillomavirus. 
HPV-matched controls also showed inconsistent associations between CIN 2/3 and hormonal contraceptive use. ${ }^{29,100-103}$ A single case-control study conducted in Costa Rica that included women with both high grade cervical lesions and invasive disease identified an association between use of COCs for $>5$ years and CIN 2/3 diagnosis; this association, however, was observed only among women with 3 or more pregnancies. ${ }^{102}$

Although the observational and experimental data suggest a distinct role of sex steroids on HPV-associated carcinogenic processes, limitations in the experimental design make it difficult to rule out a role of hormonal contraception on other endpoints in the natural history of HPV, particularly those related to HPV infection and tumor surveillance prior to the development of cancer. The cell culture and animal models showing sex steroid hormone modulation of HPV gene expression and tumorigenicity focus primarily on singledose hormone treatments administered in pregnancy-range concentrations, making it difficult to translate these results to in vivo exposures in non-pregnant women. Additionally, a majority of epidemiologic studies measured hormonal contraceptive use at a single time point at study enrollment with no consideration of duration of use (ie, "ever/never" classification used), thereby combining long- and short-term

Table 7 Summary of studies examining the relationship between hormonal contraceptive use and CIN 2/3

\begin{tabular}{|c|c|c|c|c|c|c|c|c|}
\hline Author & $\begin{array}{l}\text { Age of study } \\
\text { population } \\
\text { (range) }\end{array}$ & $\begin{array}{l}\text { Study } \\
\text { design }\end{array}$ & $\begin{array}{l}\text { Number } \\
\text { of subjects }\end{array}$ & $\begin{array}{l}\text { Number } \\
\text { of disease } \\
\text { outcomes } \\
\text { (type) }\end{array}$ & $\begin{array}{l}\text { HPV status } \\
\text { assessed at } \\
\text { single or multiple } \\
\text { timepoints }\end{array}$ & $\begin{array}{l}\text { HC method } \\
\text { Assessed }\end{array}$ & $\begin{array}{l}\text { Contraceptive } \\
\text { metric }\end{array}$ & Result \\
\hline Castle $\mathrm{PE}^{97}$ & $<30$ & $\operatorname{Pr}(\mathrm{P})$ & 1,812 & $58(\mathrm{CIN} 3)$ & single & $\mathrm{COC}$ & $\begin{array}{l}\text { Current use at } \\
\text { enrollment }\end{array}$ & $\begin{array}{l}\text { Current } \\
\text { OC use not } \\
\text { associated with } \\
\text { CIN3 }\end{array}$ \\
\hline Castle $\mathrm{PE}^{98}$ & 25 & $\operatorname{Pr}(\mathrm{A})$ & 5,060 & $\begin{array}{l}499(\mathrm{CIN} 3) \\
36 \mathrm{I}(\mathrm{CIN} 2)\end{array}$ & multiple & $\mathrm{COC}$ & $\begin{array}{l}\text { Current use; } \\
\text { former use }\end{array}$ & $\begin{array}{l}\text { No association } \\
\text { with } O C \text { use }\end{array}$ \\
\hline Deacon J100 & $25-35$ & $\mathrm{CC}$ & 898 & $232(\mathrm{CIN} 3)$ & single & $\mathrm{COC}$ & $\begin{array}{l}\text { Current use; } \\
\text { past use }\end{array}$ & No association \\
\hline Hildesheim $A^{102}$ & 34 & $\mathrm{CC}$ & 989 & II6(HSIL) & single & $\mathrm{COC}$ & $\begin{array}{l}\text { Current use; } \\
\text { duration of use }\end{array}$ & $\begin{array}{l}\text { Positive } \\
\text { association of } \\
\text { COC use }>5 \\
\text { years among } \\
\text { those with }>3 \\
\text { pregnancies }\end{array}$ \\
\hline Kjellberg $L^{103}$ & 37 & $\mathrm{CC}$ & 390 & I37(CIN2/3) & single & $\mathrm{COC}$ & Duration of use & $\begin{array}{l}\text { No association } \\
\text { after } \\
\text { adjustment for } \\
\text { HPV }\end{array}$ \\
\hline Munoz $\mathrm{N}^{101}$ & 35 & $\mathrm{CC}$ & I,037 & $525(\mathrm{CIN} 3)$ & single & $\mathrm{COC}$ & Ever/Never & No association \\
\hline Moscicki A99 & 20.4 & $\operatorname{Pr}(\mathrm{A})$ & 95 & $65(\mathrm{CIN} 2 / 3)$ & multiple & $\mathrm{COC}$ & Current use & $\begin{array}{l}\text { COC use } \\
\text { associated with } \\
\text { a reduced risk } \\
\text { of regression }\end{array}$ \\
\hline Castle $\mathrm{PE}^{98}$ & 25 & $\operatorname{Pr}(\mathrm{A})$ & 5,060 & $\begin{array}{l}499(\mathrm{CIN} 3) \\
36 \mathrm{I}(\mathrm{CIN} 2)\end{array}$ & multiple & DMPA & $\begin{array}{l}\text { Current use; } \\
\text { former use }\end{array}$ & $\begin{array}{l}\text { Current DMPA } \\
\text { use associated } \\
\text { with CIN3 }\end{array}$ \\
\hline Harris $\mathrm{T}^{29}$ & $18-50$ & $\mathrm{CC}$ & 724 & I73(CIN2/3) & single & DMPA & $\begin{array}{l}\text { Current use; } \\
\text { duration }\end{array}$ & $\begin{array}{l}\text { Use of DMPA } \\
\text { for }>2 \text { years } \\
\text { was non- } \\
\text { significantly } \\
\text { protective } \\
\text { against CIN2+ }\end{array}$ \\
\hline
\end{tabular}

Notes: $* X=$ cross-sectional; $C C=$ case-control; $\mathrm{Pr}=$ prospective $(\mathrm{P}=$ passive follow-up ; $\mathrm{A}=$ active follow-up $)$; Light gray = null association, white $=$ positive association, black = negative association. 
users into a single category, potentially diluting any effect among long-term users.

\section{Conclusions}

The relationship between hormonal contraception and HPV infection and cervical cancer risk is far from clear. At least three separate, non-mutually exclusive hypotheses have been proposed for hormone action on the various endpoints related to the natural history of HPV (Figure 1). While case-control studies make a compelling argument for the direct role of sex steroid hormones on carcinogenesis, other case-control and prospective studies, conducted to assess the association of hormonal contraceptive use with HPV-infection-related and pre-cancerous endpoints, are inconsistent. Experimental models measuring the direct effect of sex steroid hormones on HPV-related disease processes have focused primarily on the effects of these hormones in single, super-physiological concentrations on tumor formation and viral gene expression and not on infection or host response to infection. In light of the growing interest in translational medicine, collaboration between clinical investigators, epidemiologists, and laboratory scientists is needed to move this field forward.
The identification of HPV as the necessary cause of cervical cancer has facilitated the development of a highly effective prophylactic vaccine and implementation of secondary preventative strategies that utilize molecular based assays for the detection of HPV infection. Given that vaccination is prophylactic and not effective in treating pre-existing HPV infection, and that HPV DNA detection in conjunction with cytologic testing has a relatively poor positive predictive value, identification of therapeutic targets for non-surgical interventions to treat carcinoma in situ and invasive cancer still remains an important goal. This is particularly important in countries of the developing world where the burden of illness is high and access to appropriate facilities for surgical interventions is low.

While prophylactic vaccination has shown high efficacy in preventing the developing of pre-cancerous lesions, efforts to induce sterilizing immunity against a pre-existing HPV infection through the development of a therapeutic vaccine have not been successful. ${ }^{104}$ The select estrogen receptor modulator raloxifen, used for treatment of breast cancer, has recently been suggested as a therapeutic treatment for cervical carcinoma, based on the experimental and observational data

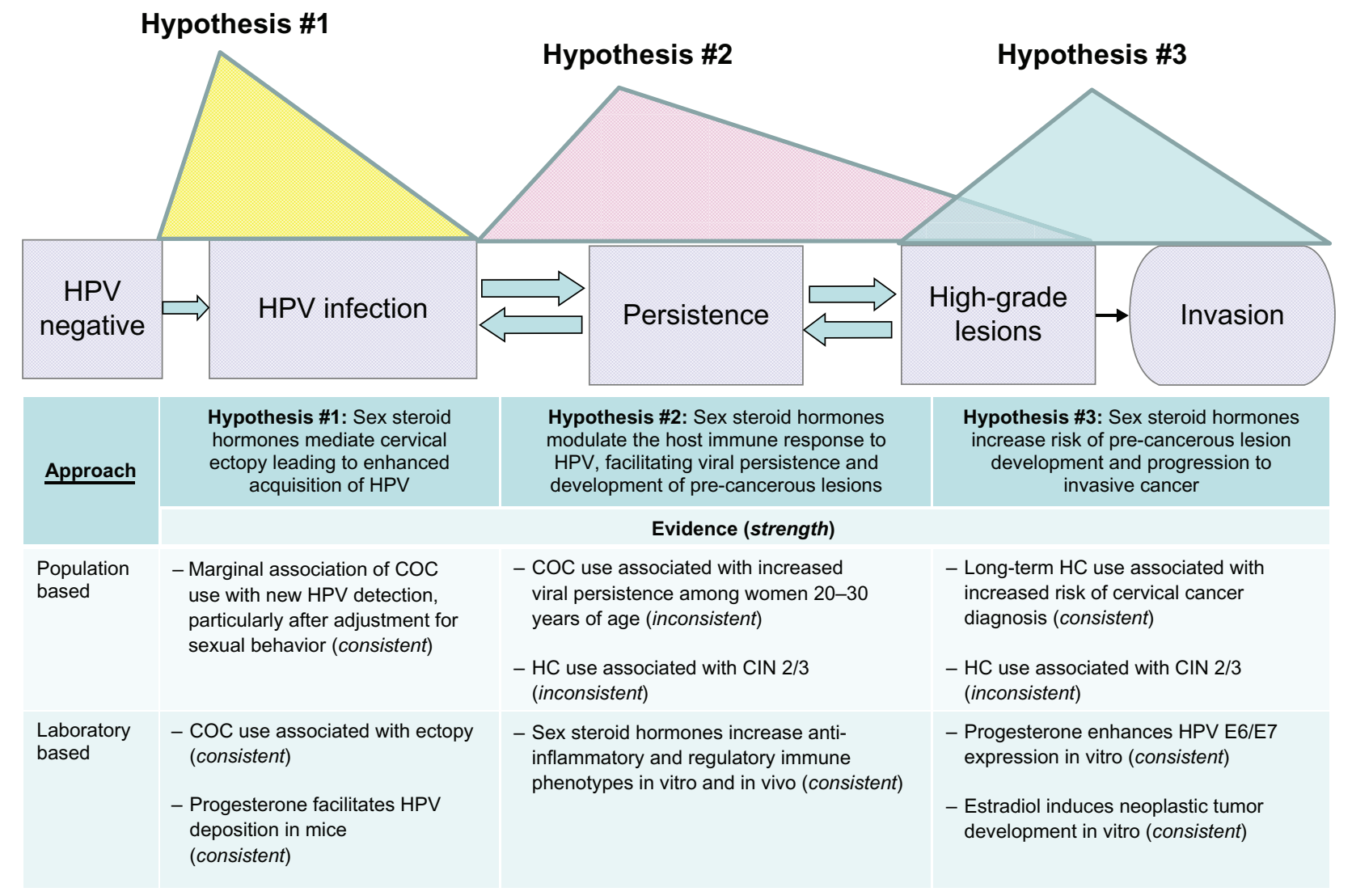

Figure I Summary of the potential biological hypotheses of the effects of sex steroid hormones on the natural history of HPV infection and cervical cancer. Abbreviations: COC, combined oral contraception; HC, hormonal contraception; HPV, human papillomavirus; CIN 2/3, cervical intraepithelial neoplasia 2/3. 
on the role of sex steroid hormones on neoplasia and cervical cancer risk. ${ }^{96,105}$ A recent sub-analysis of a large National Cancer Institute-funded trial of breast cancer and treatment with either raloxifen or another estrogen receptor antagonist, tamoxifen, was performed to evaluate the potential for these drugs in reducing cervical cancer and carcinoma in situ. ${ }^{106}$ Although the number of cervical cancer outcomes was small, these drugs showed no overall effect. While larger trials designed specifically to explore the therapeutic effects of these drugs on cervical cancer are needed to confirm these findings, first it is important to consider whether the total body of existing data on the effects of sex steroid hormones on HPV and cervical cancer provide a strong enough case to warrant such investigations.

Hormonal contraceptive use and the natural history of HPV and cervical cancer appears to be a highly dynamic interaction that is dependent on not only the duration of sex steroid hormone exposure but the stage or stages of the natural history during which this exposure occurs. In observational studies, the primary effects of hormonal contraceptive use on endpoints such as persistence as well as cancer diagnosis are observed among women who report longer-term use. In experimental models utilizing HPV16 transgenic mice, only long-term exposure to estradiol results in both the development and progression of neoplastic lesions. Conversely, shortterm use or current use among short-term users of hormonal contraceptives appears to be more closely related to virologic endpoints such as increased prevalence and new detection of HPV in observational studies. Removal of sex steroid hormone exposure, either through cessation of COC use or elimination of estradiol treatment in mouse models in case-control and experimental studies, respectively, appears to reduce the risk of cervical cancer diagnosis in case-control studies and results in spontaneous regression of lesions in mice. These data suggest that timing of hormonal exposures could be crucial.

To help clarify the temporal relationships between hormonal exposure and cervical cancer risk, observational studies exploring the role of hormonal contraception on HPV and cervical cancer should consider alternative biological mechanisms in both exposure assessment and overall study design. For example, if duration of use is a critical component of risk, studies should include women who have accumulated the immortal person-time required to estimate risks associated with long duration hormonal contraceptive use. Similarly, prospective studies designed to estimate risk of progression to CIN2+ should allow for the possibility that the association between hormonal contraceptive use and cervical cancer is mediated through an increased risk of HPV acquisition and/or persistence. Under these biological models, study designs which follow prevalently-detected HR-HPV positive women for development of CIN2+ are susceptible to significant selection bias. Cross-sectionally identified HR-HPV positive women will overselect "prevalent persistors" and will inadvertently partially match on the direct impact of hormonal contraceptive use. ${ }^{107}$

Sex steroid hormones act in complex regulatory systems that may not be observable using frequentist approaches in observational designs or reductionist experimental designs. Moving forward, elucidating the role of hormonal contraceptive use on cervical cancer development would benefit from interdisciplinary approaches. Experimental data should inform the development of biological models that can be tested in observational studies, and the observational data should be used to refine the experimental models to best reflect the in vivo state. However, the subtle, yet critical, limitations to both experimental and observational studies are often difficult to recognize across disciplines. A simple modification to the status quo that might help reconcile some of the inconsistencies reviewed here is preparation of a section of the discussion in manuscripts directed toward a broader interdisciplinary audience. A clear description of the main conclusions and an honest review of the limitations of the study, free of jargon, would be a welcome first step. Identifying mechanisms associated with increased cervical cancer risk remains a high priority, specifically because they can suggest therapeutic targets - in this case, estrogen modulators. Future research must acknowledge and accommodate the complexity of natural biological systems if we are to be effective in translating results to interventions.

\section{Disclosure}

No author has a personal or professional conflict relating to the writing of this review article.

\section{References}

1. Kamangar F, Dores GM, Anderson WF. Patterns of cancer incidence, mortality, and prevalence across five continents: defining priorities to reduce cancer disparities in different geographic regions of the world. $J$ Clin Oncol. 2006;24(14):2137-2150.

2. Schiffman M, Castle PE, Jeronimo J, Rodriguez AC, Wacholder S. Human papillomavirus and cervical cancer. Lancet. 2007;370(9590): 890-907.

3. Munoz N, Castellsague X, de Gonzalez AB, Gissmann L. Chapter 1: HPV in the etiology of human cancer. Vaccine. 2006;24S3:S1-S10.

4. Moscicki AB, Schiffman M, Kjaer S, Villa LL. Chapter 5: Updating the natural history of HPV and anogenital cancer. Vaccine. 2006;24 Suppl 3: $\mathrm{S} 3 / 42-51$

5. Moreno V, Bosch FX, Munoz N, et al. Effect of oral contraceptives on risk of cervical cancer in women with human papillomavirus infection: the IARC multicentric case-control study. Lancet. 2002;359(9312): 1085-1092. 
6. Appleby P, Beral V, Berrington de Gonzalez A, et al. Cervical cancer and hormonal contraceptives: collaborative reanalysis of individual data for 16,573 women with cervical cancer and 35,509 women without cervical cancer from 24 epidemiological studies. Lancet. 2007;370(9599): 1609-1621.

7. Smith J, Green J, de Gonzalez A, et al. Cervical Cancer and use of hormonal contraceptives: a systemic review. Lancet. 2003;361: 1159-1167.

8. Cancer ICoESoC. Comparison of risk factors for invasive squamous cell carcinoma and adenocarcinoma of the cervix: collaborative reanalysis of individual data on 8,097 women with squamous cell carcinoma and 1,374 women with adenocarcinoma from 12 epidemiological studies. Int J Cancer. 2007;120(4):885-891.

9. Siegel DM, Klein DI, Roghmann KJ. Sexual behavior, contraception, and risk among college students. J Adolesc Health. 1999;25(5): 336-343.

10. Blanc AK, Way AA. Sexual behavior and contraceptive knowledge and use among adolescents in developing countries. Stud Fam Plann. 1998;29(2):106-116.

11. Jacobson DL, Peralta L, Graham NM, Zenilman J. Histologic development of cervical ectopy: relationship to reproductive hormones. Sex Transm Dis. 2000;27(5):252-258.

12. Critchlow CW, Wolner-Hanssen P, Eschenbach DA, et al. Determinants of cervical ectopia and of cervicitis: age, oral contraception, specific cervical infection, smoking, and douching. Am J Obstet Gynecol. 1995; 173(2):534-543.

13. Harrison HR, Costin M, Meder JB, et al. Cervical Chlamydia trachomatis infection in university women: relationship to history, contraception, ectopy, and cervicitis. Am J Obstet Gynecol. 1985;153(3): 244-251.

14. Goldacre MJ, Loudon N, Watt B, et al. Epidemiology and clinical significance of cervical erosion in women attending a family planning clinic. Br Med J. 1978;1(6115):748-750.

15. Roberts JN, Buck CB, Thompson CD, et al. Genital transmission of HPV in a mouse model is potentiated by nonoxynol-9 and inhibited by carrageenan. Nat Med. 2007;13(7):857-861.

16. Roberts JN, Kines RC, Katki HA, Lowy DR, Schiller JT. Effect of pap smear collection and carrageenan on cervicovaginal human papillomavirus-16 infection in a rhesus macaque model. J Natl Cancer Inst. 2011;103(9):737-743.

17. Mauck CK, Callahan MM, Baker J, et al. The effect of one injection of Depo-Provera on the human vaginal epithelium and cervical ectopy. Contraception. 1999;60(1):15-24.

18. Kuhn L, Denny L, Pollack AE, Wright TC. Prevalence of visible disruption of cervical epithelium and cervical ectopy in African women using Depo-Provera. Contraception. 1999;59(6):363-367.

19. Green J, Berrington de Gonzalez A, Smith JS, et al. Human papillomavirus infection and use of oral contraceptives. Br J Cancer. 2003;88(11): 1713-1720

20. Burk RD, Ho GY, Beardsley L, Lempa M, Peters M, Bierman R. Sexual behavior and partner characteristics are the predominant risk factors for genital human papillomavirus infection in young women. $J$ Infect Dis. 1996;174(4):679-689.

21. Kjaer SK, van den Brule AJ, Bock JE, et al. Determinants for genital human papillomavirus (HPV) infection in 1000 randomly chosen young Danish women with normal Pap smear: are there different risk profiles for oncogenic and nononcogenic HPV types? Cancer Epidemiol Biomarkers Prev. 1997;6(10):799-805.

22. Ley C, Bauer HM, Reingold A, et al. Determinants of genital human papillomavirus infection in young women. J Natl Cancer Inst. 1991;83(14): 997-1003.

23. Marks M, Gravitt PE, Gupta SB, et al. The association of hormonal contraceptive use and HPV prevalence. Int J Cancer. 2011;128(12): 2962-2970.

24. Kotloff KL, Wasserman SS, Russ K, et al. Detection of genital human papillomavirus and associated cytological abnormalities among college women. Sex Transm Dis. 1998;25(5):243-250.
25. Pham TH, Nguyen TH, Herrero R, et al. Human papillomavirus infection among women in South and North Vietnam. Int J Cancer. 2003;104(2): 213-220.

26. Rousseau MC, Franco EL, Villa LL, et al. A cumulative case-control study of risk factor profiles for oncogenic and nononcogenic cervical human papillomavirus infections. Cancer Epidemiol Biomarkers Prev. 2000;9(5):469-476.

27. Vaccarella S, Herrero R, Dai M, et al. Reproductive factors, oral contraceptive use, and human papillomavirus infection: pooled analysis of the IARC HPV prevalence surveys. Cancer Epidemiol Biomarkers Prev. 2006;15(11):2148-2153.

28. Molano M, Posso H, Weiderpass E, et al. Prevalence and determinants of HPV infection among Colombian women with normal cytology. $\mathrm{Br}$ J Cancer. 2002;87(3):324-333.

29. Harris TG, Miller L, Kulasingam SL, et al. Depot-medroxyprogesterone acetate and combined oral contraceptive use and cervical neoplasia among women with oncogenic human papillomavirus infection. Am J Obstet Gynecol. 2009;200(5):489 e1-e8.

30. Giuliano AR, Papenfuss M, Abrahamsen M, et al. Human papillomavirus infection at the United States-Mexico border: implications for cervical cancer prevention and control. Cancer Epidemiol Biomarkers Prev. 2001;10(11):1129-1136.

31. Monroy OL, Aguilar C, Lizano M, Cruz-Talonia F, Cruz RM, RochaZavaleta L. Prevalence of human papillomavirus genotypes, and mucosal IgA anti-viral responses in women with cervical ectopy. J Clin Virol. 2010;47(1):43-48.

32. Rocha-Zavaleta L, Yescas G, Cruz RM, Cruz-Talonia F. Human papillomavirus infection and cervical ectopy. Int J Gynaecol Obstet. 2004; 85(3):259-266

33. Veress G, Csiky-Meszaros T, Czegledy J, Gergely L. Oral contraceptive use and human papillomavirus infection in women without abnormal cytological results. Med Microbiol Immunol. 1992;181(4): 181-189.

34. Nielsen A, Iftner T, Monk C, Kjaer S. Acquisition of High-Risk Human Papillomavirus Infection in a Population-Based Cohort of Danish Women. Sex Transm Dis. 2009;36(10):609-615.

35. Winer RL, Lee SK, Hughes JP, Adam DE, Kiviat NB, Koutsky LA. Genital human papillomavirus infection: incidence and risk factors in a cohort of female university students. Am J Epidemiol. 2003;157(3): 218-226.

36. Moscicki AB, Hills N, Shiboski S, Powell K, Jay N, Hanson E, et al. Risks for incident human papillomavirus infection and low-grade squamous intraepithelial lesion development in young females. JAMA. 2001;285(23):2995-3002.

37. Sellors JW, Karwalajtys TL, Kaczorowski J, et al. Incidence, clearance and predictors of human papillomavirus infection in women. CMAJ. 2003;168(4):421-425.

38. Morrison CS, Richardson BA, Mmiro F, et al. Hormonal contraception and the risk of HIV acquisition. Aids. 2007;21:85-95.

39. Marks M, Gravitt P, Gupta S, et al. Combined oral contraceptive use increases HPV persistence but not new HPV detection in a cohort of women from Thailand. J Infect Dis. 2011. In press.

40. Schlecht NF, Kulaga S, Robitaille J, et al. Persistent human papillomavirus infection as a predictor of cervical intraepithelial neoplasia. JAMA. 2001;286(24):3106-3114

41. Ho GY, Burk RD, Klein S, et al. Persistent genital human papillomavirus infection as a risk factor for persistent cervical dysplasia. J Natl Cancer Inst. 1995;87(18):1365-1371.

42. Stanley M. Immune responses to human papillomavirus. Vaccine. 2006;24(Suppl 1):S16-S22.

43. Scott ME, Ma Y, Kuzmich L, Moscicki AB. Diminished IFN-gamma and IL-10 and elevated Foxp3 mRNA expression in the cervix are associated with CIN 2 or 3. Int J Cancer. 2009;124(6):1379-1383.

44. Garcia-Pineres AJ, Hildesheim A, Herrero R, et al. Persistent human papillomavirus infection is associated with a generalized decrease in immune responsiveness in older women. Cancer Res. 2006;66(22): 11070-11076 
45. Bouman A, Heineman MJ, Faas MM. Sex hormones and the immune response in humans. Hum Reprod Update. 2005;11(4):411-423.

46. Straub RH. The complex role of estrogens in inflammation. Endocr Rev. 2007;28(5):521-574.

47. Kaushic C, Ashkar AA, Reid LA, Rosenthal KL. Progesterone increases susceptibility and decreases immune responses to genital herpes infection. J Virol. 2003;77(8):4558-4565.

48. Kaushic C, Zhou F, Murdin AD, Wira CR. Effects of estradiol and progesterone on susceptibility and early immune responses to Chlamydia trachomatis infection in the female reproductive tract. Infect Immun. 2000;68(7):4207-4216.

49. Fish EN. The X-files in immunity: sex-based differences predispose immune responses. Nat Rev Immunol. 2008;8(9):737-744.

50. Whitacre CC. Sex differences in autoimmune disease. Nat Immunol. 2001;2(9):777-780.

51. Kutteh WH, Franklin RD. Quantification of immunoglobulins and cytokines in human cervical mucus during each trimester of pregnancy. Am J Obstet Gynecol. 2001;184(5):865-872; discussion 72-74.

52. Piccinni MP. T-cell cytokines in pregnancy. Am J Reprod Immunol. 2002;47(5):289-294

53. Pacifici R, Brown C, Puscheck E, et al. Effect of surgical menopause and estrogen replacement on cytokine release from human blood mononuclear cells. Proc Natl Acad Sci U S A. 1991;88(12): 5134-5138.

54. Puder JJ, Freda PU, Goland RS, Wardlaw SL. Estrogen modulates the hypothalamic-pituitary-adrenal and inflammatory cytokine responses to endotoxin in women. $J$ Clin Endocrinol Metab. 2001;86(6): 2403-2408.

55. Kamada M, Irahara M, Maegawa M, et al. Transient increase in the levels of T-helper 1 cytokines in postmenopausal women and the effects of hormone replacement therapy. Gynecol Obstet Invest. 2001;52(2): 82-88.

56. Agarwal SK, Marshall GD Jr. Perimenstrual alterations in type-1/type-2 cytokine balance of normal women. Ann Allergy Asthma Immunol. 1999;83(3):222-228.

57. Berg G, Ekerfelt C, Hammar M, Lindgren R, Matthiesen L, Ernerudh J. Cytokine changes in postmenopausal women treated with estrogens: a placebo-controlled study. Am J Reprod Immunol. 2002;48(2): 63-69.

58. Yovel G, Shakhar K, Ben-Eliyahu S. The effects of sex, menstrual cycle, and oral contraceptives on the number and activity of natural killer cells. Gynecol Oncol. 2001;81(2):254-262.

59. Scanlan JM, Werner JJ, Legg RL, Laudenslager ML. Natural killer cell activity is reduced in association with oral contraceptive use. Psychoneuroendocrinology. 1995;20(3):281-287.

60. Rogers A, Eastell R. Effects of estrogen therapy of postmenopausal women on cytokines measured in peripheral blood. J Bone Miner Res. 1998;13(10):1577-1586

61. Franklin RD, Kutteh WH. Characterization of immunoglobulins and cytokines in human cervical mucus: influence of exogenous and endogenous hormones. J Reprod Immunol. 1999;42(2):93-106.

62. Loy RA, Loukides JA, Polan ML. Ovarian steroids modulate human monocyte tumor necrosis factor alpha messenger ribonucleic acid levels in cultured human peripheral monocytes. Fertil Steril. 1992;58(4): 733-739.

63. Ralston SH, Russell RG, Gowen M. Estrogen inhibits release of tumor necrosis factor from peripheral blood mononuclear cells in postmenopausal women. J Bone Miner Res. 1990;5(9):983-988.

64. Asai K, Hiki N, Mimura Y, Ogawa T, Unou K, Kaminishi M. Gender differences in cytokine secretion by human peripheral blood mononuclear cells: role of estrogen in modulating LPS-induced cytokine secretion in an ex vivo septic model. Shock. 2001;16(5):340-343.

65. Morishita M, Miyagi M, Iwamoto Y. Effects of sex hormones on production of interleukin-1 by human peripheral monocytes. J Periodontol. 1999;70(7):757-760.

66. Polan ML, Daniele A, Kuo A. Gonadal steroids modulate human monocyte interleukin-1 (IL-1) activity. Fertil Steril. 1988;49(6):964-968.
67. Polan ML, Loukides J, Nelson P, et al. Progesterone and estradiol modulate interleukin-1 beta messenger ribonucleic acid levels in cultured human peripheral monocytes. J Clin Endocrinol Metab. 1989;69(6): $1200-1206$.

68. Kanda N, Tsuchida T, Tamaki K. Estrogen enhancement of anti-double-stranded DNA antibody and immunoglobulin G production in peripheral blood mononuclear cells from patients with systemic lupus erythematosus. Arthritis Rheum. 1999;42(2):328-337.

69. Kanda N, Tamaki K. Estrogen enhances immunoglobulin production by human PBMCs. J Allergy Clin Immunol. 1999;103(2 Pt 1):282-288.

70. Pauklin S, Sernandez IV, Bachmann G, Ramiro AR, Petersen-Mahrt SK. Estrogen directly activates AID transcription and function. $J$ Exp Med. 2009;206(1):99-111.

71. Matalka KZ, Ali DA. Stress-induced versus preovulatory and pregnancy hormonal levels in modulating cytokine production following whole blood stimulation. Neuroimmunomodulation. 2005;12(6):366-374.

72. Prieto GA, Rosenstein Y. Oestradiol potentiates the suppressive function of human $\mathrm{CD} 4 \mathrm{CD} 25$ regulatory $\mathrm{T}$ cells by promoting their proliferation. Immunology. 2006;118(1):58-65.

73. Karpuzoglu E, Fenaux JB, Phillips RA, Lengi AJ, Elvinger F, Ansar Ahmed S. Estrogen up-regulates inducible nitric oxide synthase, nitric oxide, and cyclooxygenase- 2 in splenocytes activated with $\mathrm{T}$ cell stimulants: role of interferon-gamma. Endocrinology. 2006;147(2): 662-671.

74. Correale J, Arias M, Gilmore W. Steroid hormone regulation of cytokine secretion by proteolipid protein-specific $\mathrm{CD} 4+\mathrm{T}$ cell clones isolated from multiple sclerosis patients and normal control subjects. J Immunol. 1998;161(7):3365-3374.

75. Marks MA, Gravitt PE, Burk RD, Studentsov Y, Farzadegan H, Klein SL. Progesterone and 17beta-estradiol enhance regulatory responses to human papillomavirus type 16 virus-like particles in peripheral blood mononuclear cells from healthy women. Clin Vaccine Immunol. 2010; 17(4):609-617.

76. Mjosberg J, Svensson J, Johansson E, et al. Systemic Reduction of Functionally Suppressive CD4dimCD25highFoxp3+ Tregs in Human Second Trimester Pregnancy Is Induced by Progesterone and 17betaEstradiol. J Immunol. 2009;183(1):759-769.

77. Piccinni MP, Scaletti C, Maggi E, Romagnani S. Role of hormonecontrolled Th1- and Th2-type cytokines in successful pregnancy. J Neuroimmunol. 2000;109(1):30-33.

78. Kaushic C, Ashkar AA, Reid LA, Rosenthal KL. Progesterone increases susceptibility and decreases immune responses to genital herpes infection. J Virol. 2003;77(8):4558-4565.

79. Schiffman M, Kjaer SK. Chapter 2: Natural history of anogenital human papillomavirus infection and neoplasia. J Natl Cancer Inst Monogr. 2003(31):14-19.

80. Richardson H, Abrahamowicz M, Tellier PP, et al. Modifiable risk factors associated with clearance of type-specific cervical human papillomavirus infections in a cohort of university students. Cancer Epidemiol Biomarkers Prev. 2005;14(5):1149-1156.

81. Sycuro LK, Xi LF, Hughes JP, et al. Persistence of genital human papillomavirus infection in a long-term follow-up study of female university students. J Infect Dis. 2008;198(7):971-978.

82. Shew ML, Fortenberry JD, Tu W, et al. Association of condom use, sexual behaviors, and sexually transmitted infections with the duration of genital human papillomavirus infection among adolescent women. Arch Pediatr Adolesc Med. 2006;160(2):151-156.

83. Nielsen A, Kjaer SK, Munk C, Osler M, Iftner T. Persistence of highrisk human papillomavirus infection in a population-based cohort of Danish women. J Med Virol. 2010;82(4):616-623.

84. Munoz N, Hernandez-Suarez G, Mendez F, et al. Persistence of HPV infection and risk of high-grade cervical intraepithelial neoplasia in a cohort of Colombian women. Br J Cancer. 2009;100(7):1184-1190.

85. Molano M, Van den Brule A, Plummer M, et al. Determinants of clearance of human papillomavirus infections in Colombian women with normal cytology: a population-based, 5-year follow-up study. $\mathrm{Am} J$ Epidemiol. 2003;158(5):486-494. 
86. Maucort-Boulch D, Plummer M, Castle PE, et al. Predictors of human papillomavirus persistence among women with equivocal or mildly abnormal cytology. Int J Cancer. 2010;126(3):684-691.

87. Chen YH, Huang LH, Chen TM. Differential effects of progestins and estrogens on long control regions of human papillomavirus types 16 and 18. Biochem Biophys Res Commun. 1996;224(3):651-659.

88. Mitrani-Rosenbaum S, Tsvieli R, Tur-Kaspa R. Oestrogen stimulates differential transcription of human papillomavirus type 16 in $\mathrm{SiHa}$ cervical carcinoma cells. J Gen Virol. 1989;70(Pt 8):2227-2232.

89. Mittal R, Tsutsumi K, Pater A, Pater MM. Human papillomavirus type 16 expression in cervical keratinocytes: role of progesterone and glucocorticoid hormones. Obstet Gynecol. 1993;81(1):5-12.

90. Ruutu M, Wahlroos N, Syrjanen K, Johansson B, Syrjanen S. Effects of 17 beta-estradiol and progesterone on transcription of human papillomavirus $16 \mathrm{E} 6 / \mathrm{E} 7$ oncogenes in CaSki and $\mathrm{SiHa}$ cell lines. Int $J$ Gynecol Cancer. 2006;16(3):1261-1268.

91. Kim CJ, Um SJ, Kim TY, et al. Regulation of cell growth and HPV genes by exogenous estrogen in cervical cancer cells. Int J Gynecol Cancer. 2000;10(2):157-164.

92. Hwang JY, Lin BY, Tang FM, Yu WC. Tamoxifen stimulates human papillomavirus type 16 gene expression and cell proliferation in a cervical cancer cell line. Cancer Res. 1992;52(24):6848-6852.

93. Brake T, Lambert PF. Estrogen contributes to the onset, persistence, and malignant progression of cervical cancer in a human papillomavirustransgenic mouse model. Proc Natl Acad Sci U S A. 2005;102(7): 2490-2495.

94. Shai A, Brake T, Somoza C, Lambert PF. The human papillomavirus E6 oncogene dysregulates the cell cycle and contributes to cervical carcinogenesis through two independent activities. Cancer Res. 2007; 67(4):1626-1635.

95. Arbeit JM, Howley PM, Hanahan D. Chronic estrogen-induced cervical and vaginal squamous carcinogenesis in human papillomavirus type 16 transgenic mice. Proc Natl Acad Sci U S A. 1996;93(7):2930-2935.

96. Chung SH, Lambert PF. Prevention and treatment of cervical cancer in mice using estrogen receptor antagonists. Proc Natl Acad Sci USA. 2009;106(46):19467-19472.
97. Castle PE, Wacholder S, Lorincz AT, et al. A prospective study of high-grade cervical neoplasia risk among human papillomavirusinfected women. J Natl Cancer Inst. 2002;94(18):1406-1414.

98. Castle PE, Walker JL, Schiffman M, Wheeler CM. Hormonal contraceptive use, pregnancy and parity, and the risk of cervical intraepithelial neoplasia 3 among oncogenic HPV DNA-positive women with equivocal or mildly abnormal cytology. Int J Cancer. 2005;117(6):1007-1012.

99. Moscicki AB, Ma Y, Wibbelsman C, et al. Rate of and risks for regression of cervical intraepithelial neoplasia 2 in adolescents and young women. Obstet Gynecol. 2010;116(6):1373-1380.

100. Deacon JM, Evans CD, Yule R, et al. Sexual behaviour and smoking as determinants of cervical HPV infection and of CIN3 among those infected: a case-control study nested within the Manchester cohort. Br J Cancer. 2000;83(11):1565-1572.

101. Munoz N, Bosch FX, de Sanjose S, et al. Risk factors for cervical intraepithelial neoplasia grade III/carcinoma in situ in Spain and Colombia. Cancer Epidemiol Biomarkers Prev. 1993;2(5):423-431.

102. Hildesheim A, Herrero R, Castle PE, et al. HPV co-factors related to the development of cervical cancer: results from a population-based study in Costa Rica. Br J Cancer. 2001;84(9):1219-1226.

103. Kjellberg L, Hallmans G, Ahren AM, et al. Smoking, diet, pregnancy and oral contraceptive use as risk factors for cervical intra-epithelial neoplasia in relation to human papillomavirus infection. Br J Cancer. 2000;82(7):1332-1338.

104. Trimble CL, Frazer IH. Development of therapeutic HPV vaccines. Lancet Oncol. 2009;10(10):975-980.

105. Chung SH, Franceschi S, Lambert PF. Estrogen and ERalpha: Culprits in cervical cancer? Trends Endocrinol Metab. 2010 Apr 22.

106. Castle PE. Do selective estrogen receptor modulators treat cervical precancer and cancer? Time to pool data from relevant trials. Int J Cancer. 2011;128(4):997-998.

107. Plummer M, Schiffman M, Castle PE, Maucort-Boulch D, Wheeler CM. A 2-year prospective study of human papillomavirus persistence among women with a cytological diagnosis of atypical squamous cells of undetermined significance or low-grade squamous intraepithelial lesion. J Infect Dis. 2007;195(11):1582-1589.
Open Access Journal of Contraception

\section{Publish your work in this journal}

Open Access Journal of Contraception is an international, peerreviewed, open access, online journal, publishing original research, reports, reviews and commentaries on all areas of contraception. In addition to clinical research, demographics and health-related aspects, the journal welcomes new findings in animal and preclinical studies

\section{Dovepress}

relating to understanding the biological mechanisms and practical development of new contraceptive agents. The manuscript management system is completely online and includes a very quick and fair peer-review system. Visit http://www.dovepress.com/testimonials.php to read real quotes from published authors. 